\title{
A STUDY OF THE DISTRIBUTION OF TRADITIONAL HOUSES WITH DOMICAL VAULT ROOFS IN IRAN AND AFGHANISTAN
}

\author{
イランおよびアフガニスタンにおけるドーム状ヴォールト屋根伝統住居の分布に関する研究 \\ Khojesta KAWISH ${ }^{* 1}$, Tetsuya ANDO ${ }^{* 2}$ and Sayed Abdul Basir SAMIMI*3 \\ コジャスタ カウィッシュ, 安藤 徹哉, サミミサイードアブドゥルバシール
}

\begin{abstract}
This study examines the distribution of traditional houses with domical vault roofs in Eastern Iran and Western Afghanistan to determine its boundary as well as the factors that impact their distribution. High-resolution satellite images, old photographs and literature from Iran, and satellite images and data from field surveys in Afghanistan have been used to determine their distribution. The findings of the study include maps showing the distribution of traditional houses with domical vault roofs which suggest that climatic and cultural factors are significant in determining prevalent types of roofs.
\end{abstract}

Keywords: Iran, Afghanistan, traditional house, domical vault roof, distribution イラン, アフガニスタン, 伝統住居, ドーム状ヴォールト屋根, 分布

\section{Introduction}

\subsection{Background of research}

Traditional houses in each region are built with locally available and climatically suitable materials reflecting the natural environment of the location. They are also the outcomes of the culture of a region, reflecting the history and lifestyle of its people. The construction technologies for building traditional houses have spread across regions where people share a common culture, including language.

Traditional houses with curved construction roofs are seen in various parts of the world where the climate is relatively dry. However, the construction methods and shapes of these roofs vary. In the Northern Nigeria, there are traditional houses with domical vault roofs which are called Hausa compounds. They have domical vault roofs which have a shell-shaped structure. The frame is made with plants and laminated with mud (Ogura 1992, pp.83-88).

From Iran to Afghanistan (Fig.1), there are several types of curved roof constructions. Some of them have very distinctive domical shapes, described as sail vaults by Rudofsky (1964). They are domical vault roofs made of masonry structures with sun dried or fired bricks. While travelling from Europe to Iran through Turkey for a field survey of traditional villages in the mid-1970s, Hiroshi Hara and his research group observed traditional houses with such domical vault roofs only in the eastern part of Iran (Hara et al. 1977, pp. 138-167).i) This particular type of house left a strong impression on Hara, who conducted extensive surveys of vernacular architecture in the world. Nearly four decades later, in a lecture titled 'Discovering Villages in the World' (2015), Hara described the houses as having unusual shapes of domical roofs...they have two main curvatures and the average curvature of the two curves are made of sun dried bricks. It is amazing, they are seen in common from the desert of Iran in the west to Afghanistan in the east. They are indeed idiosyncratic.' ${ }^{\text {ii) }}$ In the same survey, within Iran, they recorded traditional houses with flat roofs in an area stretching from the coastal region of the Caspian Sea to the west of the desert region.

This study attempts to identify the distribution of traditional houses with domical vault roofs using satellite image analysis (Google Maps, Google Earth and Zoom Earth), field

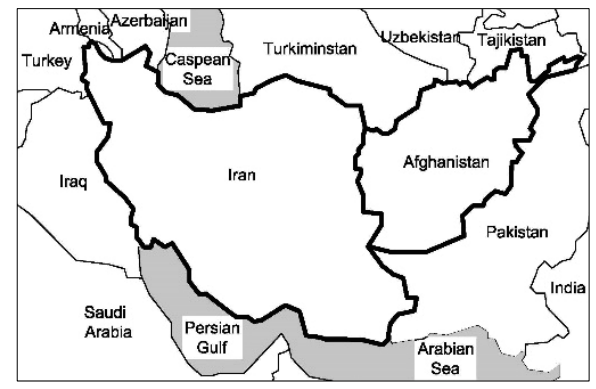

Fig. 1 Map of Iran and Afghanistan
* 1 Lect., Dept. of Urban Engineering, Faculty of Engineering, Herat University, Dr.Eng.

* 2 Prof., Dept. of Civil Engineering and Architecture, Faculty of Engineering, University of the Ryukyus, Dr.Eng.

*3 Lect., Dept. of Urban Engineering, Faculty of Engineering, Herat University, Dr.Eng. ヘラート大学工学部都市工学科＼cjkstart講師・博十(工学) 琉球大学工学部環境建設工学科 教授·博士 (工学) ヘラート大学工学部都市工学科 講師・博士 (工学) 
surveys, and old photographs. Although there exist curved roof constructions with flatter tops, they are not included in this study as they are not identifiable from satellite images. For example, according to Sazabo et al 1991, traditional houses located in the Afghan province of Qandahar have barrel vault structures which support the roofs but are covered by pot-sherds and dirt to create a flat surface.

The existing literature on traditional houses with domical vault roofs in this region is limited. "Technologie de la Voute” (Besenval 1984) presents the construction of domical vault structures in the region across Iran, Afghanistan and Turkmenistan, including both residential and monumental buildings. These areas were ruled under the same empire over several periods in history and therefore share a common culture. In Iran, the three volumes of Hejazi et al. (2014) describe the history and detailed features of Persian architecture and the technology of constructing traditional structures, including vault and dome construction. In particular, the reconstruction methods used in Bam which had become a ruin due to the earthquake are described in detail. However, the distribution of traditional houses with domical vault roofs has not been undertaken as an area of research.

In comparison with monumental architecture, ordinary houses in Afghanistan have not been taken on as a research subject. "Afghanistan: an Atlas of Indigenous, Domestic Architecture" (Szabo et al. 1991) is a comprehensive study on houses which classifies traditional dwellings in Afghanistan. It indicates that traditional houses with domical vault roofs are distributed throughout western Afghanistan ${ }^{\mathrm{iii}}$ while traditional houses in eastern Afghanistan have flat roofs (Szabo 1991, p. 119 and p.134). Thus, it is assumed that traditional houses with domical vault roofs in masonry structures are distributed from eastern Iran to western Afghanistan while outside of the region, houses have flat roofs. In our previous study (Kawish et al. 2017), traditional houses with domical vault roofs in masonry structures in Herat, Afghanistan were examined in detail including construction methods (Fig.2). This study attempts to examine how they are distributed in the wider region of Iran and Afghanistan.

\subsection{Method of research}

The aims of the study are 1) to determine the boundary of the area where traditional houses with domical vault roofs are distributed in Iran and Afghanistan, and 2) to comprehensively analyze the factors which determine their distribution. With regards to the first aim, chapter 2 examines the distribution of traditional houses with domical vault roofs in both Iran and Afghanistan by determining the types of roofs found in all provincial capitals and several other cities/villages of each province. According to Hara's observation and our pre-survey, we understand that traditional houses with domical vault roofs are concentrated in desert areas around the border of Iran and Afghanistan. Thus, in Iran we began our investigation of domical vault roofs from east to west and in Afghanistan from west to east. In the fringe areas of Iran towards the west and Afghanistan towards the east where there are both traditional houses with domical vault roofs and flat roofs,

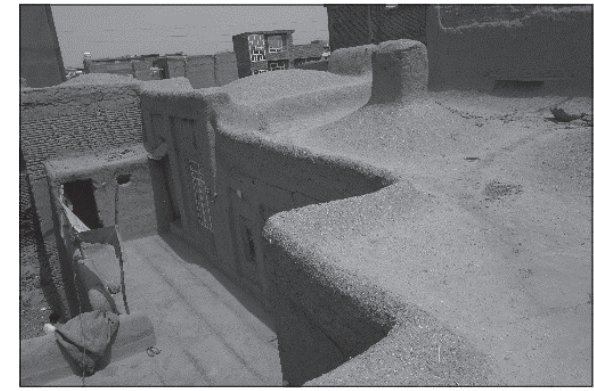

Fig. 2 Traditional house with domical vault roofs in Herat (Photograph by K. Kawish 2016)

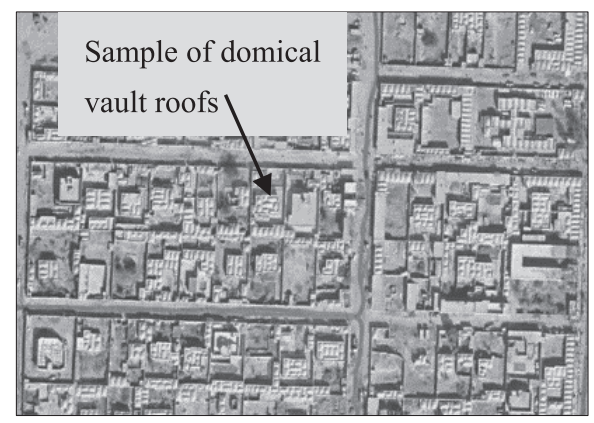

Fig. 3 Traditional houses with domical vault roofs in Zaranj Afghanistan (Google Earth) investigation was done more thoroughly in order to determine the boundary of the distribution. The types of roofs found in each city/village are investigated via satellite images (Fig.3). In the case of Iran, old photographs were also used as substitutes in areas where traditional houses with domical vault roofs had assumedly already been replaced by new houses with flat roofs. In the case of Afghanistan, field surveys were conducted in areas where suitable satellite images were not available. With regards to the second aim, chapters 3 discusses impact factors on the distribution of traditional houses with domical vault roofs in Iran and Afghanistan from climate and historical/cultural aspects. A conclusion is then drawn in chapter 4.

\section{Distribution of traditional houses with domical vault roofs}

\subsection{Iran}

In this study, the distribution of traditional houses with domical vault roofs in Iran was initially examined through high resolution satellite images via Google Maps, Google Earth and Zoom Earth in 2017. iv) 104 areas including 31 provincial capitals and 73 other cities/villages in Iran were examined through high resolution satellite images v), and 57 areas were found to have traditional houses with domical vault roofs (Fig. 4 and Table.1). In the capital of Qazvin province, we could not find traditional houses with domical vault roofs via satellite images, but were able to locate them in old photographs. vi) In addition, through examining the existing literature, Dezful city was found to have had traditional houses with domical vault roofs. vii) The area within the boundary of traditional houses with domical vault roofs in Iran calculated was $795,270.5 \mathrm{~km}^{2}$ and it occupied $48.2 \%$ of the total area of the country $\left(1,648,000 \mathrm{~km}{ }^{2}\right.$. Thus, traditional houses 
with domical vault roofs are one of the main types of residential construction in central and eastern Iran.

\subsection{Afghanistan}

To determine the distribution of traditional houses with domical vault roofs in Afghanistan, high resolution satellite images via Google Maps/Google Earth and Zoom Earth in 2017 were also used. However, such images were limited in terms of availability compared with Iran, where most of the cities/villages have high resolution satellite images available. In particular, satellite images were not available for the rural part of eastern Afghanistan. Therefore, field surveys were conducted in Afghanistan to examine the roof types of houses. In total, 128 areas including 34 provincial capitals and 94 cities/villages were studied. 78 areas were examined through high resolution satellite images viii) and 50 areas were examined through field surveys conducted in April 2017 (Fig.5 and Table 2). Altogether, 90 provincial capitals and cities/villages were found to have traditional houses with domical vault roofs in Afghanistan. Although traditional houses with domical vault roofs are found in cities/villages in Kunduz and Zabul provinces, they are not found in their provincial capitals. The area within the boundary of traditional houses with domical vault roofs in Afghanistan calculated was $268,924 \mathrm{~km}^{2}$ and it occupied $41.2 \%$ of the total area of the country $\left(652,864 \mathrm{~km}^{2}\right)$. Thus, traditional houses with domical vault roofs are one of the main types of residential construction in the western part of Afghanistan. By comparing the domical vault boundary of Afghanistan determined in this study and the boundary shown by Szabo et al. (1991), it is found that the boundary of this study is much larger. It includes the Zabul, Kandahar, Urozgan, Daykondi, Ghor, Sar-e Pol and Kunduz provinces which have not been included in the boundary shown by Szabo et al. (1991).

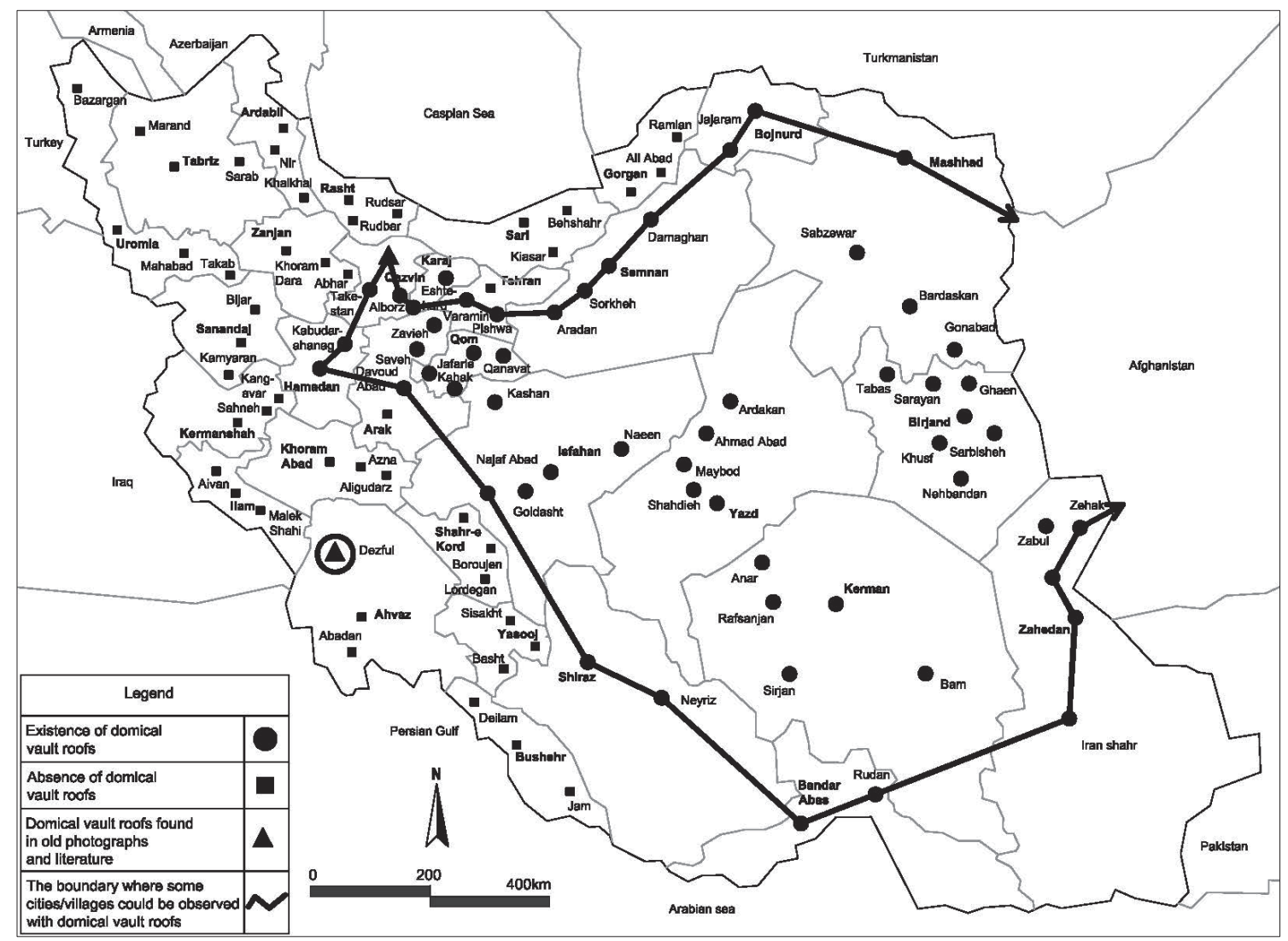

Fig. 4 Distribution of traditional houses with domical vault roofs in Iran (Drawing by K. Kawish 2017)

\section{Impact factors on the distribution of traditional houses with domical vault roofs in Iran and Afghanistan}

\subsection{Climatic conditions}

\subsubsection{Precipitation}

Firstly, the distribution of traditional houses with domical vault roofs and the average annual precipitation are analyzed. The average annual precipitation of all provincial capitals and some remote cities/villages in Iran and Afghanistan are examined through two sources (data from the World Bank and Climate-data Organization) ix) (Fig.6, Tables 1 and 2). In this study, precipitations of each cities/villages are categorized into five groups (-99mm, 100-199mm, 200-299mm, 300-399mm, 400mm-). If two sources show different groups, the city/village is categorized into the group with higher precipitation.

Among the 104 cities/village we investigated in Iran, 15 cites/villages did not have any available climate data. Thus, we investigated the average annual precipitation for the remaining 89 cities/villages. Among the 48 cities/villages where traditional house with domical vault 
roofs are observed and where climate data are available, 4 cities/villages have precipitation less than $99 \mathrm{~mm}, 20$ cities/villages have precipitation of 100-199mm, 16 cities/villages have precipitation of $200-299 \mathrm{~mm}$ and 8 cities/villages have precipitation of $300-399 \mathrm{~mm}$. There are no cities/villages that have precipitation of more than $400 \mathrm{~mm}$. The distribution of each precipitation group shows that within the domical vault roof boundary of Iran, the climate changes from east to west - from drier (200-299mm) to driest (-199mm) to dry (300-399mm)

In Afghanistan, among the 128 cities/village we investigated, 52 cites/villages did not have any available climate data. Thus, we

Table 1 Distribution of traditional houses with domical vault roofs in Iran

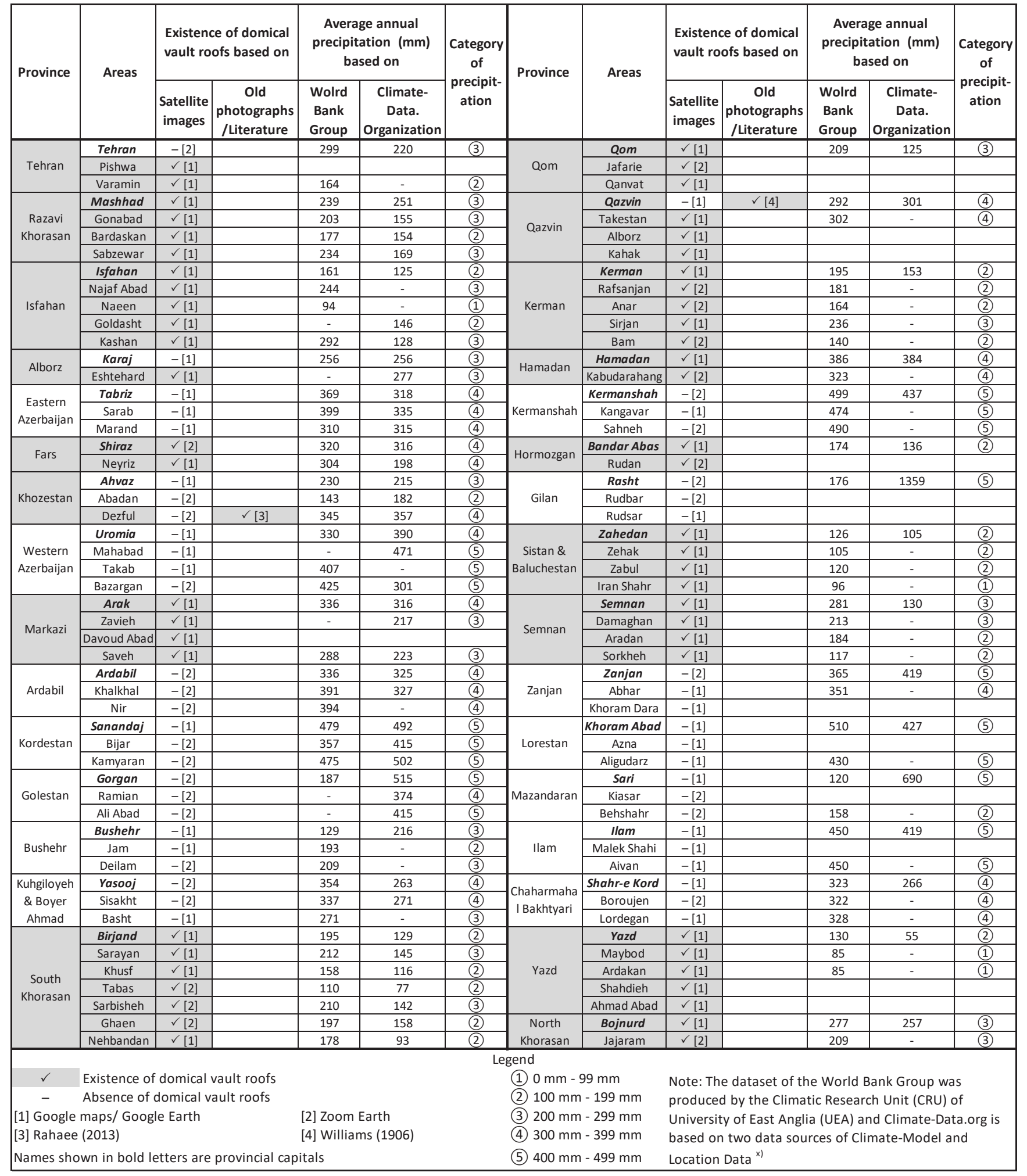


investigated the average annual precipitation for the remaining 76 cities/villages. Among the 52 cities/villages where traditional house with domical vault roofs are observed and where climate data are available, no city/village had precipitation of less than $99 \mathrm{~mm}, 12$ cities/villages have precipitation of 100-199mm, 26 cities/villages have precipitation of $200-299 \mathrm{~mm}$ and 14 cities/villages have precipitation of $300-399 \mathrm{~mm}$. There are no cities/villages that have precipitation of more than $400 \mathrm{~mm}$. The distribution of each precipitation group shows that within the domical vault boundary in Afghanistan, the climate changes from south to north - from driest (-199mm) to drier (200-299mm) to dry (300-399mm) and drier (200-299mm).

The cities/villages where traditional houses with domical vault roofs are observed in Iran and Afghanistan are in the dry region where the average annual precipitation is less than $400 \mathrm{~mm}$. The driest $(-199 \mathrm{~mm})$ area has a desert climate, while the drier (200-299mm) and dry $(300-399 \mathrm{~mm})$ areas have a step climate. Desert and step climate areas face a shortage of wood. The mountains under such climates are barren and have few trees, making it difficult to procure wood for construction. The scarcity of wood in the arid areas of Iran and Afghanistan has led to the prevalence of domical vault roof construction as this form of architecture does not require wooden beams to support the roofs. Thus, sun-dried mud bricks made with earth are the cheapest construction material and domical vault roofs are the most rational decision. Average annual precipitation is therefore relevant to determine the distribution of traditional houses with domical vault roofs.

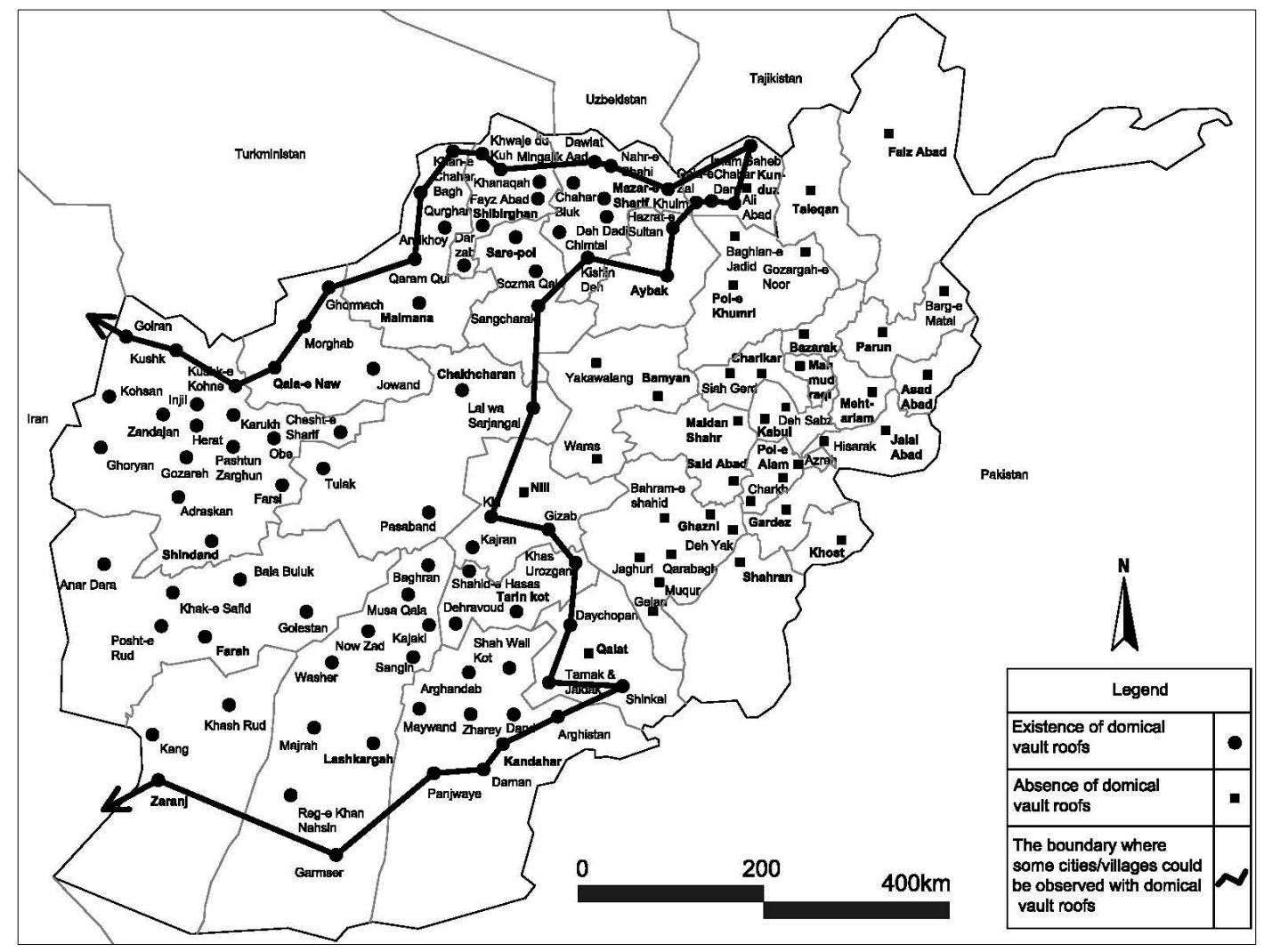

Fig. 5 Distribution of traditional houses with domical vault roofs in Afghanistan

\subsubsection{Temperature}

Fathy (1986) explained that domical vault roofs were chosen for traditional houses because of their shape which allows air circulation even in a hot climate. Although this is correct, the monthly average temperature in fact ranges widely from very high to low in the areas containing traditional houses with domical vault roofs. For instance, the monthly average temperature in Arak city in Iran and Zaranj city in Afghanistan ranges from $34.6^{\circ} \mathrm{C}$ to $-10.6^{\circ} \mathrm{C}$ and $42.5^{\circ} \mathrm{C}$ to $0.5^{\circ} \mathrm{C}$ respectively. ${ }^{\mathrm{x}}$ ) Considering the low temperatures experienced even in desert regions, it is necessary to consider other reasons for the use of domical vault roofs.

In our previous study (Kawish et al. 2017), we found that the thickness of domical vault roofs in Herat is more than $40 \mathrm{~cm}$. The walls of traditional houses that support the weight of domical vault roofs are very thick, varying from $50 \mathrm{~cm}$ to $120 \mathrm{~cm}$. The thick masonry walls and roofs of these houses provide high insulation. They are effective not only during the summer but also during the winter and at night when the temperature drops considerably. Small openings also contribute to keep the interior cool in summer and warm in winter. 
Table 2 Distribution of traditional houses with domical vault roofs in Afghanistan

\begin{tabular}{|c|c|c|c|c|c|c|c|c|c|c|c|c|c|}
\hline \multirow{2}{*}{ Province } & \multirow{2}{*}{ Areas } & \multicolumn{2}{|c|}{$\begin{array}{c}\text { Existence of } \\
\text { domical vault } \\
\text { roofs based on }\end{array}$} & \multicolumn{2}{|c|}{$\begin{array}{c}\text { Average annual } \\
\text { precipitation }(\mathrm{mm}) \\
\text { based on }\end{array}$} & \multirow{2}{*}{$\begin{array}{c}\text { Category } \\
\text { of } \\
\text { precipit- } \\
\text { ation }\end{array}$} & \multirow{2}{*}{ Province } & \multirow{2}{*}{ Areas } & $\begin{array}{r}\text { Existe } \\
\text { domic } \\
\text { roofs b }\end{array}$ & $\begin{array}{l}\text { nce of } \\
\text { l vault } \\
\text { ased on }\end{array}$ & $\begin{array}{r}\text { Aver } \\
\text { precipi } \\
\text { b }\end{array}$ & $\begin{array}{l}\text { age annual } \\
\text { tation }(\mathrm{mm}) \\
\text { ased on }\end{array}$ & $\begin{array}{c}\text { Category } \\
\text { of }\end{array}$ \\
\hline & & $\begin{array}{c}\text { Satellite } \\
\text { images }\end{array}$ & $\begin{array}{l}\text { Field } \\
\text { survey }\end{array}$ & $\begin{array}{l}\text { Wolrd } \\
\text { Bank } \\
\text { Group }\end{array}$ & $\begin{array}{c}\text { Climate- } \\
\text { Data. } \\
\text { Organization }\end{array}$ & & & & $\begin{array}{c}\text { Satellite } \\
\text { images }\end{array}$ & $\begin{array}{l}\text { Field } \\
\text { survey }\end{array}$ & $\begin{array}{l}\text { Wolrd } \\
\text { Bank } \\
\text { Group }\end{array}$ & \begin{tabular}{|} 
Climate- \\
Data. \\
Organization
\end{tabular} & $\begin{array}{c}\text { precipit- } \\
\text { ation }\end{array}$ \\
\hline & Qala-e Naw & $\checkmark[2]$ & & 275 & 356 & (4) & & Cakhcharan & $\checkmark[1]$ & & 344 & - & (4) \\
\hline Badghis & Morghab & $\checkmark[2]$ & & 217 & 326 & (4) & Ghor & Lal wa Sarjangal & & $\checkmark$ & 364 & - & (4) \\
\hline Baagnis & Jowand & & $\checkmark$ & & & & Ghor & \begin{tabular}{|l|} 
Tulak \\
\end{tabular} & $\checkmark[2]$ & & & & \\
\hline & Ghormach & $\checkmark[2]$ & & 233 & - & (3) & & Pasaband & $\checkmark[2]$ & & & & \\
\hline & Bamyan & & - & 476 & 117 & (5) & & Pol-e Khumri & $-[2]$ & & 444 & 282 & (5) \\
\hline Bamyan & Yakawalang & & - & 422 & - & (5) & Baghlan & Gozargah-e Noor & & - & & & \\
\hline & Waras & & - & 399 & - & (4) & & Baghlan-e Jadid & $-[2]$ & & & & \\
\hline Wardak & Maidan Shahr & & - & 491 & 373 & (5) & Noprictan & Parun & & 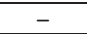 & 658 & - & (5) \\
\hline Wardak & Said Abad & & - & & & & Nooristan & Barg-e Matal & & - & & & \\
\hline Panuan & Charikar & $-[2]$ & & 499 & 412 & (5) & Kabul & Kabul & $-[1]$ & & 499 & 362 & (5) \\
\hline rairwain & Siah Gerd & $-[2]$ & & & & & Naivui & Deh Sabz & $-[1]$ & & & & \\
\hline & Sar-e Pol & $\checkmark[2]$ & & 237 & 233 & (3) & & Zaranj & $\checkmark[1]$ & & 105 & 54 & (2) \\
\hline Sar-e Pol & Sangcharak & & $\checkmark$ & & & & Nimruz & Kang & $\checkmark[2]$ & & & & \\
\hline & Sozma Qala & $\checkmark[2]$ & & & & & & Khash Rud & $\checkmark[2]$ & & 142 & - & (2) \\
\hline & Shibirghan & $\checkmark[1]$ & & 198 & 213 & (3) & & Farah & $\checkmark[1]$ & & 159 & 78 & (2) \\
\hline & Khwaje Du Koh & $\checkmark[2]$ & & & & & & Khak-e Safid & $\checkmark[2]$ & & 183 & - & (2) \\
\hline Jawzian & Mingajik & $\checkmark[2]$ & & & & & Farah & Bala Buluk & $\checkmark[1]$ & & & & \\
\hline Jawzjan & Darzab & $\checkmark[2]$ & & 288 & - & (3) & Farah & Posht-e Rud & $\checkmark[2]$ & & & & \\
\hline & Khanaqah & $\checkmark[2]$ & & & & & & Anar Dara & & $\checkmark$ & 173 & - & (2) \\
\hline & Fayz Abad & $\checkmark[2]$ & & & & & & Golestan & & $\checkmark$ & 226 & - & (3) \\
\hline & Maimana & & $\checkmark$ & 275 & 372 & (4) & & Kunduz & $-[1]$ & & 313 & 325 & (4) \\
\hline & Qaram Qul & & $\checkmark$ & & & & & Chahar Dara & $\checkmark[2]$ & & & & \\
\hline Faryab & Andkhoy & & $\checkmark$ & 198 & 281 & (3) & Kunduz & Ali Abad & & $\checkmark$ & 335 & - & (4) \\
\hline & Qurghan & & $\checkmark$ & & & & & Imam Saheb & & $\checkmark$ & 314 & - & (4) \\
\hline & Khan-e Chahar Bagh & & $\checkmark$ & & & & & Qala-e Zal & $\checkmark[2]$ & & & & \\
\hline & Nili & & - & 342 & - & (4) & & Qalat & $-[2]$ & & 276 & 283 & (3) \\
\hline Davkondi & Kajran & & $\checkmark$ & 301 & - & (4) & 7ahul & Tarnak \& Jaldak & $\checkmark[2]$ & & 258 & - & (3) \\
\hline Daykondı & Kiti & & $\checkmark$ & 314 & - & (4) & Zabul & Shinkai & & $\checkmark$ & & & \\
\hline & Gizab & & $\checkmark$ & - & 206 & (3) & & Daychopan & & $\checkmark$ & 370 & - & (4) \\
\hline Laghman & Mehtarlam & & - & 598 & 355 & (5) & Khost & Khost & $-[2]$ & & 561 & 446 & (5) \\
\hline Badakhshan & Faiz Abad & $-[2]$ & & 495 & 497 & (5) & Kapisa & Mahmud Raqi & & $\begin{array}{llll}- & & & \\
\end{array}$ & 542 & 437 & (5) \\
\hline Paktika & Shahran & & - & 457 & 265 & (5) & Paktia & Gardez & $-[2]$ & & 561 & 340 & (5) \\
\hline Takhar & Taleqan & $-[2]$ & & 445 & 434 & (5) & Kunar & Asad Abad & & 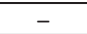 & 731 & 532 & (5) \\
\hline Samangan & Aybak & & $\checkmark$ & 355 & - & (4) & Nangarhar & Jalal abad & $-[2]$ & & 659 & 206 & (5) \\
\hline Samangan & Hazrat-e Sultan & & $\checkmark$ & & & & Nangarhar & Hisarak & & 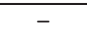 & & & \\
\hline & Herat & $\checkmark[1]$ & & 236 & 265 & (3) & & Kandahar & $\checkmark[1]$ & & 208 & 176 & (3) \\
\hline & Kushk-e Kohne & $\checkmark[2]$ & & & & & & Daman & $\checkmark[2]$ & & & & \\
\hline & Pashtun Zarghun & $\checkmark[2]$ & & 236 & - & (3) & & Dand & $\checkmark[1]$ & & & & \\
\hline & Zandajan & & $\checkmark$ & & & & & Arghandab & $\checkmark[1]$ & & & & \\
\hline & Chesht-e Sharif & & $\checkmark$ & 299 & - & (3) & Kandahar & Arghistan & $\checkmark[2]$ & & & & \\
\hline & Farsi & & $\checkmark$ & 272 & - & (3) & & Zharey & & $\checkmark$ & & & \\
\hline & Golran & & $\checkmark$ & & & & & Maywand & $\checkmark[2]$ & & 201 & - & (3) \\
\hline Herat & Kohsan & $\checkmark[2]$ & & 219 & - & (3) & & Panjwaye & $\checkmark[1]$ & & 203 & - & (3) \\
\hline Herat & Shindand & $\checkmark[2]$ & & 203 & 168 & (3) & & Shah Wali Kot & & $\checkmark$ & & & \\
\hline & Ghoryan & & $\checkmark$ & 212 & - & (3) & & Ghazni & & - & 460 & 254 & (5) \\
\hline & Kushk & $\checkmark[2]$ & & & & & & \begin{tabular}{|l|} 
Jaghuri \\
\end{tabular} & & - & & & \\
\hline & Obe & $\checkmark[2]$ & & 285 & - & (3) & & Qarabagh & & - & & & \\
\hline & Adraskan & $\checkmark[2]$ & & 230 & 216 & (3) & Ghazni & Bahram-e Shahid & & - & & & \\
\hline & Karukh & $\checkmark[2]$ & & 263 & 301 & (4) & & Muqur & $-[2]$ & & & & \\
\hline & Gozareh & $\checkmark[2]$ & & 235 & - & (3) & & Gelan & $-[2]$ & & 350 & - & (4) \\
\hline & Injil & $\checkmark[2]$ & & & & & & Deh Yak & $-[2]$ & & & & \\
\hline & Lashkargah & $\checkmark[1]$ & & 156 & 97 & (2) & & Mazar-e sharif & $\checkmark[2]$ & & 238 & 180 & (3) \\
\hline & Sangin & $\checkmark[1]$ & & 184 & 143 & (2) & & Dawlat Abad & $\checkmark[2]$ & & & & \\
\hline & Washer & & $\checkmark$ & 181 & - & (2) & & Kishin Deh & $\checkmark[2]$ & & & & \\
\hline & Baghran & $\checkmark[2]$ & & 301 & - & (4) & & Chimtal & $\checkmark[2]$ & & & & \\
\hline & Musa Qala & $\checkmark[2]$ & & - & 159 & (2) & Balkh & Chahar Bluk & $\checkmark[2]$ & & & & \\
\hline Helmand & Kajaki & $\checkmark[2]$ & & 216 & 163 & (3) & & Khulm & $\checkmark[2]$ & & 264 & - & (3) \\
\hline & Reg-e Khan Nashin & $\checkmark[2]$ & & & & & & Nahr-e Shahi & $\checkmark[1]$ & & & & \\
\hline & Now Zad & & $\checkmark$ & 190 & 162 & (2) & & Deh Dadi & $\checkmark[1]$ & & & & \\
\hline & Majrah & $\checkmark[2]$ & & 156 & - & (2) & & Tarin kot & $\checkmark[2]$ & & 247 & 241 & (3) \\
\hline & Garmser & $\checkmark[1]$ & & 142 & - & (2) & & Shahid-e Hasas & & $\checkmark$ & & & \\
\hline & Pol-e Alam & $-[2]$ & & 562 & 291 & (5) & Urozgan & Dehravoud & & $\checkmark$ & 255 & - & (3) \\
\hline Logar & Charkh & $-[2]$ & & & & & & Khas Urozgan & & $\checkmark$ & 334 & - & (4) \\
\hline & Azrah & & - & & & & Panjshir & Bazarak & $-[2]$ & & 599 & 647 & (5) \\
\hline & & Lege & & & & & (1) $0 \mathrm{~mm}$ - & $99 \mathrm{~mm}$ & & & & & \\
\hline$\checkmark$ & Existence of domical & vault roof & & & & & (2) $100 \mathrm{mn}$ & $m-199 m m$ & & & & & \\
\hline- & Absence of domical $v$ & vault roofs & & & & & (3) $200 \mathrm{mn}$ & $n-299 m m$ & & & & & \\
\hline [1] Google ma & aps/ Google Earth & & & [2] Zoom & Earth & & (4) $300 \mathrm{mn}$ & $n-399 m m$ & & & & & \\
\hline Names showr & $\mathrm{n}$ in bold letters are p & rovincial ca & apitals & & & & (5) $400 \mathrm{mn}$ & $m-499 m m$ & & & & & \\
\hline
\end{tabular}


It can be argued that the shape of the domical vault roofs was not chosen to withstand a hot climate, but rather that building domical vault roofs with sun dried bricks was a rational decision in wood-scarce areas. The thick walls provided effective insulation in a desert climate with a wide range of temperatures, a factor which may have promoted the spread and adoption of this building technology in the region.

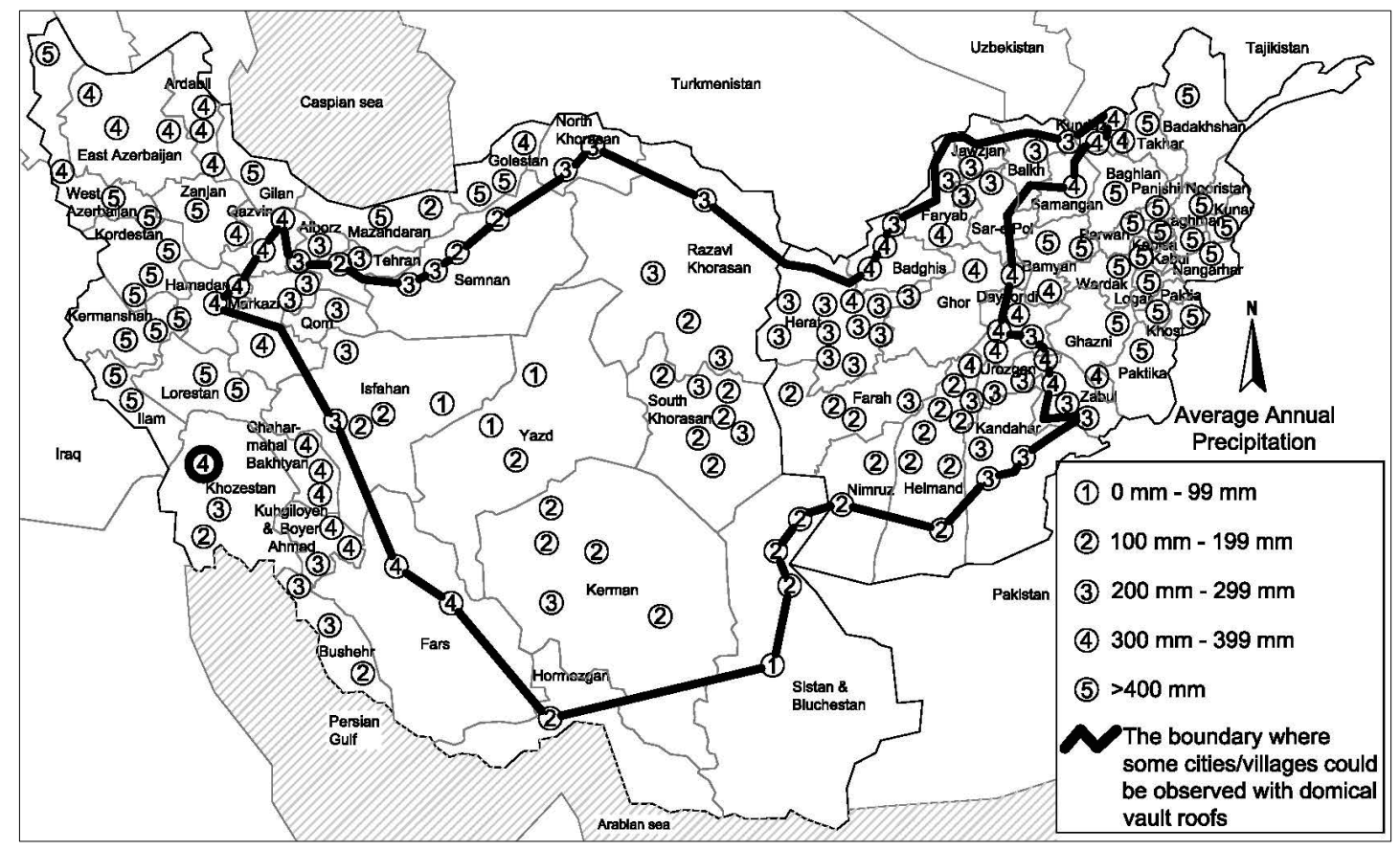

Fig. 6 Average annual precipitation of provincial capitals in Iran and Afghanistan (Drawing by K. Kawish 2017)

\subsection{Historical background / Cultural aspect}

The use of arch, vault and cupola dome building systems in construction can be traced back to the most ancient times. As early as the $3^{\text {rd }}$ millennium BC, primitive forms of curved roof construction were used in countries in the Middle East and Egypt. Arches, vaults and cupolas were also widely used by Roman, Sassanid (226-651 AD) and Byzantine (476-1453 AD) builders before being adopted in many regions of Europe (Joffroy et al. 1994). The construction method of building a shallow dome on a square plan supported by four arches and spherical corners, or pendentives in the Roman architecture of Levant, was already mentioned by Choisy (1899, vol.1, pp.518-519). The history of monumental buildings with domed roofs in Persia began during the Sassanid period at a palace in Firoz Abad Fars, Iran, in the early $3^{\text {rd }}$ century (Hejazi et al. 2014). Masjid-e Tarikh (mosque of history) also known as Noh Gonbad Haji Pyade or Nine Dome Mosque was constructed in the late $8^{\text {th }}$ to early $9^{\text {th }}$ century in Balkh. It is one of the oldest existing mosques in Afghanistan (Saoud 2005). The first congregational mosque in Herat, Majid-e Jame, was constructed in late $10^{\text {th }}$ to early $11^{\text {th }}$ century. It may mean the construction technology of mosques with dome roofs transferred from north to south in Afghanistan during the Abbasid Caliphate period (750-1258 AD), the first Islamic (Sunni) empire under Arabic influence.

It is unknown when and where domical vault roofs in masonry construction with sun dried bricks for houses originated. Unlike monumental buildings, no records remain for houses. It is hard to examine whether they have kept the same types of houses since the beginning of the city. Timur used architects from Syria and Egypt to build palaces in the gardens of Samarkand (Kawaguchi 2014).

Hăfiż-i Abrū(-1430), the famous historian in the Timurid period(1502-1736 AD) wrote; 'in Samarkand, buildings are generally constructed with soil and wood. There are earthquakes in Samarkand, but they are not large. Thus, the walls are made of wood and their surface is covered with soil' (Kawaguchi 2014: 204). Timur also constructed palaces in the gardens of Herat, which were often used as a parliament. While Samarkand and Herat became two important cities at the end of the Timurid period (1502-1736 AD), there is no information on houses in that period. In Uzbekistan, traditional houses in Samarkand and Bukhara (Gangler et al. 2004) have flat roofs. The average annual precipitation (World Bank) of Samarkand is about $310 \mathrm{~mm}$ and that of Bukhara is about $149 \mathrm{~mm}$. In Afghanistan, traditional houses in Herat have domical vault roofs although the average annual precipitation of Herat is about 236mm. Traditional houses in Ali Abad near the border to Uzbekistan also have domical vault roofs, and the average annual precipitation is $335 \mathrm{~mm}$. Therefore, precipitation is not the only factor in determining the distribution of traditional houses with domical vault roofs.

The city of Bam (Fig.7) in Iran is well-known for the historical citadel of Arg-e Bam, which is about 2000 years old (Zare 2004). Bam has been inhabited since the Achaemenieds period (550-330 BC), but apart from the citadel, most of its structures originate from the Safavid 
period (1370-1507 AD) (Rouhi 2003). The city of Bam represents an outstanding example of a fortified settlement and citadel in the Central Asia region, using a mud layer technique (Chineh) combined with sun-dried bricks (UNESCO 2004). There are various types of curved roofs including domical vault roofs (Hejazi et al. 2014). A photo taken in 2001 ${ }^{\mathrm{x})}$ shows that the citadel of Bam also incorporated Dalans (walkways covered by vaults). Sun-dried brick domical vault roofs and Dalans in the city of Bam have similar features with those found in the Herat Old City. The ancient city of Bam was mostly destroyed in the 2003 Bam earthquake (Zare 2004) but was completely restored afterwards. Isfahan (Fig.7), the capital of the Safavid dynasty during 1598-1736 also used to have numerous traditional houses with domical vault roofs, built with sun-dried bricks. However, most of them have since been replaced.

Herat (Fig.7) in western Afghanistan has more than 2500 years of history. Although the city wall of the Herat Old City was completed in the $10^{\text {th }}$ century, construction of the Herat Old City took place mostly during the Timurid period (Najimi 1976). According to Isofzari, who lived in the Timurid period, most buildings in the Herat Old City were covered with wood and few were built with fired bricks (Abru 1970). This explanation is similar to the description of Samarkand by Hāfiz-i Abrū. However it is not clear if these brick buildings included houses. In Herat, wood which was used to cover ceilings and internal walls came from the Badghis desert and mountains where suitable trees grew.

In Herat, curved roof constructions can be grouped into two main types, domical vaults and barrel vaults (Kawish 2017), while Bam's curved roof construction types are more diverse. It is uncertain if this is related to the propagation process of the construction technology of domical vault roofs. However, compared to Bam, it is hard to trace the history of curved roof construction in Herat because old houses have been replaced by new ones. The oldest existing traditional houses in Herat are around 110 years old (Kawish et al. 2017). Drawings of Herat citadel in the late $1^{\text {th }}$ century show densely built houses with domical vault roofs in the Herat Old City. Information on houses in Herat before then is very limited.

The distribution of traditional houses with domical vault roofs found in this study is mostly within the traditional borders of the Persian Empires (Fig.7). In Herat City today, the words used for domical vault roof construction are in the Dari language, which is within the Persian family (Kawish et al. 2017). It is easily assumed that the shared language greatly affected the dissemination of building technology. It may be hypothesized that the use of domical vault roofs for houses became popular after the Abbasid Caliphate, probably around the Timurid period or the Safavid period, but this requires further research. Field surveys in both Iran and Afghanistan are necessary in order to examine how they became popular in the region.

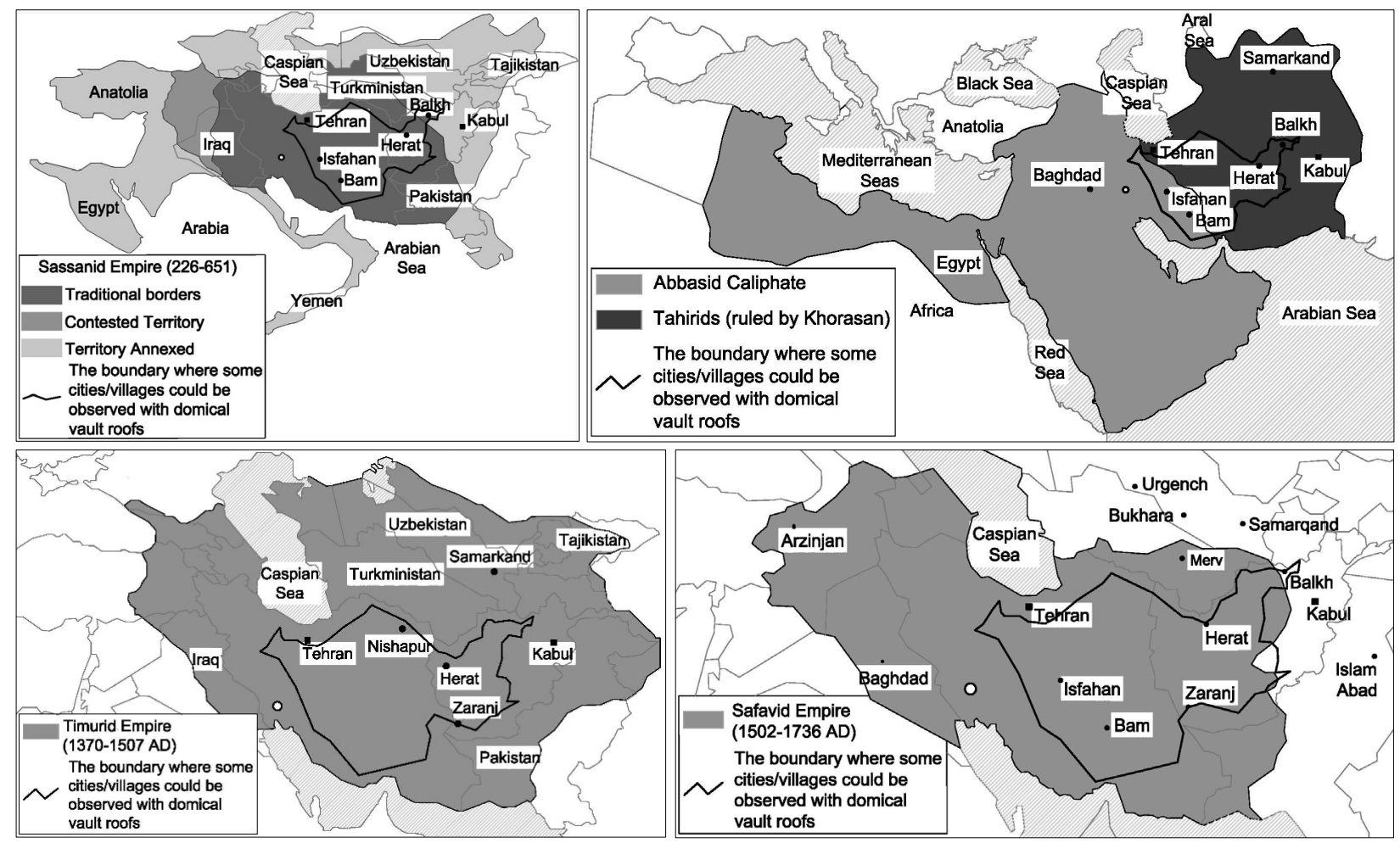

Fig. 7 The Sassanid Empire, Abbasid Caliphate, Timurid Empire, Safavid Empire and the outer boundary where some cities/villages could be observed with domical vault roofs (Drawings by K. Kawish 2018 based on (Source for Sassanid Empire: https://www.ancient.eu/image/1190/territorial-expansion-of-the-sasanian-empire//), $\quad$ (Source Abbasid Caliphate: http://www.indiana.edu/ cahist/Readings/2011Spring/Abbasid\%20Caliphate.pdf), (Source for Timurid and Safavid Empires: Arab Atlas http://iranpoliticsclub.net/maps/)) 


\section{Conclusion}

This study provides a basic map where traditional houses with domical vault roofs are found mostly based on satellite images. To determine the exact boundary of domical vault roof construction, further research is needed, including on-site field surveys.

The cities/villages where traditional house with domical vault roofs are observed in Iran and Afghanistan are in the dry region where the average annual precipitation is less than $400 \mathrm{~mm}$. The distribution of each precipitation group shows that within the domical vault roof boundary of Iran, the climate changes from east to west - from drier (200-299mm) to driest (-199mm) and dry (300-399mm). The distribution of each precipitation group shows that within the domical vault boundary in Afghanistan, the climate changes from south to north - from driest $(-199 \mathrm{~mm})$ to drier $(200-299 \mathrm{~mm})$ to dry $(300-399 \mathrm{~mm})$ to drier $(200-299 \mathrm{~mm})$. The driest $(-199 \mathrm{~mm})$ area has a desert climate and the drier $(200-299 \mathrm{~mm})$ and dry $(300-399 \mathrm{~mm})$ areas have step climates. In the desert and step climate areas of Iran and Afghanistan, the scarcity of wood has led to the prevalence of domical vault roof construction as this form of architecture does not require wooden beams to support the roofs. Thus, precipitation is an important factor behind the distribution of traditional houses with domical vault roofs.

Comparison of precipitation and roof types shows that precipitation may not be the only factor determining the distribution of traditional houses with domical vault roofs. The distribution of traditional houses with domical vault roofs found in this study is mostly within the traditional borders of the Persian Empires. It may be hypothesized that the use of domical vault roofs for houses became popular after the Abbasid Caliphate, probably around the Timurid period or the Safavid period, but this requires field surveys in both Iran and Afghanistan in order to examine how they became popular in the region. For example, the fortified settlement of Zaranj located between Herat and Bam on the Afghan side of the Iran-Afghanistan border was destroyed in the Timurid period, but by examining the ruins and records of the old city (whether or not there were domical vault roofs), it may be possible to obtain information on the propagation of traditional houses with domical vault roofs.

\section{References}

1) Ogura, N.: Afurica no jutaku [Houses in Africa], Maruzen, 1992 (in Japanese).

2) Rudofsky, B.: Architecture without architects. Doubleday \& Company, Inc., 1964.

3) Hara, H. et al: To॰o, chuto chiiki no keitaironteki kosatsu, jukyo shugoron (2) [Physical analysis of houses in Eastern Europe and Middle East], Kajima shuppankai, 1977 (in Japanese).

4) Szabo, A. and Barfield, T. J.: Afghanistan an Atlas of Indigenous Domestic Architecture, University of Texas Press, 1991

5) Besenval, R.: Technologie de la voute dans l'Orient ancient, Recherche sur les civilisations, 1984 (in French).

6) Hejazi, M. and Mehdizadeh, F: Persian Architectural Heritage (Architecture), WIT Press, 2014

7) Hejazi, M. and Mehdizadeh, F.: Persian Architectural Heritage (Structure), WIT Press, 2014

8) Hejazi, M. and Mehdizadeh, F: Persian Architectural Heritage (Conservation), WIT Press, 2014

9) Kawish et al: A Study of Traditional Houses with Domical Vaults in Herat, Afghanistan, Journal of Architecture and Planning (Transactions of AIJ), Vol.82, No.740, pp.2741-2750, 2017.10

10) Williams, J.: Persia Past and Present: Macmillan \& Co., Ltd, 1906

11) Rahaee, O.: Indigenous and Local Construction Materials in Dezful Architecture- Using Reed in Traditional Buildings, First Regional Architecture Conference, Sustainable Architecture and Urbanism, 2013 (in Persian).

12) Fathy, H.:Natural Energy and Vernacular Architecture, Principles and Examples with Reference to Hot Arid Climates, The University of Chicago Press, 1986

13) Joffroy, T. and Guillaud, H.: The Basics of Building with Arches, Vaults and Cupolas, SKAT Publication, 1994

14) Choisy, A. : Histoire de I'architecture, Gauthier-Villars, Imprimeur-Libraire, vol.1, 1899

15) Saoud, R.:Masjid-I Tarikh at Balkh, Foundation for Science, Technology and Civilization, 2005

16) Kawaguchi, T.: Timur Empire, Koudansha, 2014 (in Japanese).

17) Gangler, A., Gaube, H. and Petruccioli, A.: Bukhara-The Eastern Dome of Islam, Menges, 2004

18) Zare, M. : Bam, Iran Earthquake of 26 December 2003, Mw6.5: A Study on The Strong Ground Motions, 13th World Conference on Earthquake Engineering, 2004

19) Rouhi, J. : Conservation and Restoration of Adobe Architectural Heritage of Bam Citadel (Iran), Affected by the 26 December 2003 Bam Earthquake: Problems and Issues, University of Naples Federico II, 2017

20) UNESCO World Heritage Centre: Bam and its Cultural Landscape, Nomination File 1208bis (https://whc.unesco.org/uploads/nominations/1208bis.pdf), 2004 (accessed 2019.2..1)

21) National Institute of Informatics: Digital Silk Road Project, Digital Archives of Cultural Heritage, (http://dsr.nii.ac.jp/bam/collection/000036-000040.html.en) (accessed 2019.2.1)

22) Najimi, A.W.: Herat: the Islamic City, A Study in Urban Conservation, Scandinavian Institute of Asian Studies/Curzon Press, 1988

23) Abru, H.:Joghraphyaye Hafez Abru, Entesharat Bonyad Farhang Iran, 1970 (in Persian). 
24) https://www.ancient.eu/image/1190/territorial-expansion-of-the-sasanian-empire// (accessed 2019.2.2)

25) http://www.indiana.edu/ cahist/Readings/2011Spring/Abbasid\%20Caliphate.pdf (accessed 2019.2.2)

26) http://iranpoliticsclub.net/maps/ (accessed 2019.2.2)

\section{Notes}

i) They didn't survey Afghanistan at that time.

ii) March 15, 2015, Waseda University, Tokyo. The content of the lecture can be found at 10+1 website (http://10plus1.jp/monthly/2015/07/pickup-02.php).

iii) However, it does not show how the data were collected and our examination shows different results as discussed later.

iv) Satellite images are from the following sources.

[1] Google map website (https://maps.google.com)/ Google Earth.

[2] Zoom Earth website (https://zoom.earth/).

v) The coordinates of domical vault roof houses observed in provincial capitals and cities/villages in Iran via satellite images in 2017 are as below:

Pishwa $\left(35.295575^{\circ}, 51.710771^{\circ}\right)$, Varamin $\left(35.206833^{\circ}, 51.676825^{\circ}\right)$, Mashhad $\left(36.311792^{\circ}, 59.692740^{\circ}\right)$, Gonabad $\left(34.336576^{\circ}, 58.703634^{\circ}\right)$, Bardaskan $^{\circ}$

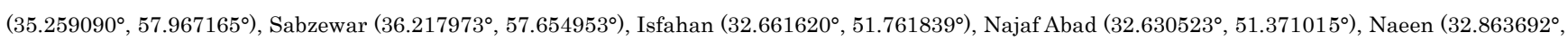
$\left.53.086396^{\circ}\right)$, Goldasht $\left(32.629550^{\circ}, 51.442900^{\circ}\right)$, Kashan $(33.980351,51.449543)$, Eshtehard $\left(35.724782^{\circ}, 50.368021^{\circ}\right)$, Shiraz $\left(29.611819^{\circ}, 52.546255^{\circ}\right)$, Neyriz $\left(29.205416^{\circ}, 54.335128^{\circ}\right)$, Arak $\left(34.090361^{\circ}, 49.691837^{\circ}\right)$, Zavieh $\left(35.382195^{\circ}, 50.564644^{\circ}\right)$, Davoud Abad $\left(34.289135^{\circ}, 4^{\circ} .852236^{\circ}\right)$, Saveh $^{\circ}$ $\left(35.015351^{\circ}, 50.351433^{\circ}\right)$, Birjand $\left(32.881063^{\circ}, 59.215211^{\circ}\right)$, Sarayan $\left(33.856259^{\circ}, 58.513264^{\circ}\right)$, Khusf $\left(32.776996^{\circ}, 58.881138^{\circ}\right)$, Tabas $\left(33.596813^{\circ}\right.$, $\left.56.915096^{\circ}\right)$, Sarbisheh $\left(32.571767^{\circ}, 59.796366^{\circ}\right)$, Ghaen $\left(33.730806^{\circ}, 59.196364^{\circ}\right)$, Nehbandan $\left(31.536504^{\circ}, 60.036008^{\circ}\right)$, Qom $\left(34.658001^{\circ}, 50.855913^{\circ}\right)$, Jafarie $\left(34.776140^{\circ}, 50.515677^{\circ}\right)$, Qanvat (34.617470, $\left.51.027556^{\circ}\right)$, Takestan $\left(36.063774^{\circ}, 49.713338^{\circ}\right)$, Alborz $\left(36.139111^{\circ}, 50.054569^{\circ}\right)$, Kahak $^{\circ}(36.112263$, 49.760926), Kerman (30.270429 $\left.9^{\circ}, 57.079011^{\circ}\right)$, Rafsanjan (30.399983 $\left.{ }^{\circ}, 55.996916^{\circ}\right)$, Anar (30.872013, 55.274227), Sirjan (29.408866, 55.667909), Bam $\left(29.102953^{\circ}, 58.366244^{\circ}\right)$, Hamadan $\left(34.880342^{\circ}, 48.517784^{\circ}\right)$, Kabudarahang $\left(35.210683^{\circ}, 48.723257^{\circ}\right)$, Bandar Abas $\left(27.182209^{\circ}, 56.293456^{\circ}\right)$, Rudan $^{\circ}$ $\left(27.449369^{\circ}, 57.227964^{\circ}\right)$, Zahedan $\left(29.494864^{\circ}, 60.868191^{\circ}\right)$, Zehak (30.895039, $\left.61.680111^{\circ}\right)$, Zabul $\left(31.039970^{\circ}, 61.491654^{\circ}\right)$, Iran Shahr $^{\circ}\left(27.200430^{\circ}\right.$, $\left.60.696793^{\circ}\right)$, Semnan $\left(35.567591^{\circ}, 53.399173^{\circ}\right)$, Damaghan $\left(36.168781^{\circ}, 54.348409^{\circ}\right)$, Aradan $\left(35.249594^{\circ}, 52.493335^{\circ}\right)$, Sorkheh $\left(35.461986^{\circ}, 53.210912^{\circ}\right)$, Yazd $\left(31.894110^{\circ}, 54.363634^{\circ}\right)$, Maybod $\left(32.251270^{\circ}, 54.020524^{\circ}\right)$, Ardakan $\left(32.307925^{\circ}, 54.026333^{\circ}\right)$, Shahdieh $\left(31.937630^{\circ}, 54.293026^{\circ}\right)$, Ahmad Abad $\left(32.359544^{\circ}, 53.989422^{\circ}\right)$, Bojnurd $\left(37.461612^{\circ}, 57.326605^{\circ}\right)$, Jajaram $\left(36.952721^{\circ}, 56.381257^{\circ}\right)$

vi) The references of photographs used to investigate traditional houses with domical vault roofs in provincial capitals in Iran are as below:

[3] Rahaee 2013.

[4] Williams 1906.

vii) Although we could not find traditional houses with domical vault roofs in Dezful city in Khozestan province via satellite images, traditional houses in Dezful city had been covered with domical vault roofs unlike houses in other areas on the southern boundary of Iran according to Rahaee (2013, p.2).

viii) The coordinates of domical vault roof houses observed in provincial capitals and cities/villages in Afghanistan via satellite images in 2017 are as below: Qala-e Naw $\left(34.983520^{\circ}, 63.122236^{\circ}\right)$, Morghab (35.580649 $\left.{ }^{\circ}, 63.331375^{\circ}\right)$, Ghormach $\left(35.705956^{\circ}, 63.999376^{\circ}\right)$, Sar-e Pol $^{\circ}\left(36.220171^{\circ}, 65.930740^{\circ}\right)$, Sozma $^{\circ}$

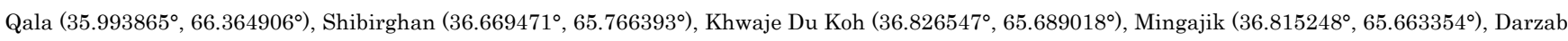
$\left(35.975002^{\circ}, 65.378614^{\circ}\right)$, Khanaqah $\left(36.857082^{\circ}, 66.191631^{\circ}\right)$, Fayz Abad $\left(36.717214^{\circ}, 66.733676^{\circ}\right)$, Herat $\left(34.354310^{\circ}, 62.202830^{\circ}\right)$, Kushk $^{\circ}$ e Kohne $\left(34.870602^{\circ}, 62.505943^{\circ}\right)$, Pashtun Zarghun (34.324874 $\left.{ }^{\circ}, 62.447495^{\circ}\right)$, Kohsan $\left(34.653337^{\circ}, 61.199469^{\circ}\right)$, Shindand $\left(33.309807^{\circ}, 62.138638^{\circ}\right)$, Kushk $^{\circ}$ $\left(34.956878^{\circ}, 62.240642^{\circ}\right)$, Obe $\left(34.373263^{\circ}, 63.208991^{\circ}\right)$, Adraskan $\left(33.635385^{\circ}, 62.289600^{\circ}\right)$, Karukh $\left(34.485352^{\circ}, 62.593397^{\circ}\right), \mathrm{Gozareh}^{\circ}\left(34.221603^{\circ}\right.$, $\left.62.222934^{\circ}\right)$, Injil $\left(34.321597^{\circ}, 62.211053^{\circ}\right)$, Lashkargah $\left(31.589599^{\circ}, 64.368370^{\circ}\right)$, Sangin $\left(32.056385^{\circ}, 64.851208^{\circ}\right)$, Baghran $^{\circ}\left(33.053264^{\circ}, 65.095140^{\circ}\right)$, Musa Qala $\left(32.344697^{\circ}, 64.754143^{\circ}\right)$, Kajaki $\left(32.282340^{\circ}, 65.067145^{\circ}\right)$, Reg-e Khan Nashin $\left(30.550360^{\circ}, 63.784357^{\circ}\right), \mathrm{Majrah}^{\circ}\left(31.537190^{\circ}, 64.085191^{\circ}\right)$, Garmser $\left(31.130813^{\circ}, 64.210703^{\circ}\right)$, Cakhcharan $\left(34.522525^{\circ}, 65.256556^{\circ}\right)$, Tulak $\left(34.059351^{\circ}, 63.527146^{\circ}\right)$, Pasaband $\left(33.538461^{\circ}, 64.977748^{\circ}\right)$, Zaranj $^{\circ}$ $\left(30.956910^{\circ}, 6^{2} 859900^{\circ}\right)$, Kang $\left(31.183813^{\circ}, 61.849268^{\circ}\right)$, Khash Rud $\left(31.529427^{\circ}, 62.791382^{\circ}\right)$, Farah $\left(32.372916^{\circ}, 62.112819^{\circ}\right)$, Khak $^{-e}$ Safid

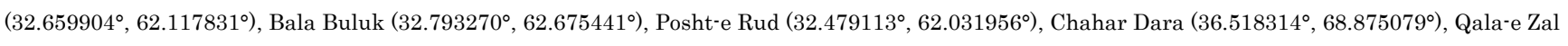
$\left(36.965950^{\circ}, 68.569430^{\circ}\right)$, Tarnak \& Jaldak $\left(31.787839^{\circ}, 66.344077^{\circ}\right)$, Kandahar $\left(31.615136^{\circ}, 65.712609^{\circ}\right)$, Daman $\left(31.562253^{\circ}, 66.335204^{\circ}\right)$, Dand $^{\circ}$ $\left(31.617337^{\circ}, 65.633941^{\circ}\right)$, Arghandab (31.607058 $\left.{ }^{\circ}, \quad 65.651712^{\circ}\right)$, Arghistan $\left(31.558888^{\circ}, 66.596038^{\circ}\right)$, Maywand $^{\circ}\left(31.632477^{\circ}, 65.043287^{\circ}\right)$, Panjwaye $\left(31.524427^{\circ}, 65.497355^{\circ}\right)$, Mazar-e sharif $\left(36.703791^{\circ}, 67.116798^{\circ}\right)$, Dawlat Abad $\left(37.019957^{\circ}, 66.942833^{\circ}\right)$, Kishin Deh $\left(36.142465^{\circ}, 66.944091^{\circ}\right)$, Chimtal $^{\circ}$ $\left(36.639375^{\circ}, 66.916092^{\circ}\right)$, Chahar Bluk $\left(36.672589^{\circ}, 66.927214^{\circ}\right)$, Khulm $\left(36.699662^{\circ}, 67.724705^{\circ}\right)$, Nahr-e Shahi $\left(36.672845^{\circ}, 67.010036^{\circ}\right)$, Deh Dadi $\left(36.669033^{\circ}, 67.017082^{\circ}\right)$, Tarin kot $\left(32.616035^{\circ}, 65.869919^{\circ}\right)$

ix) We used both websites "Climate-Data. Org." (https://en.climate-data.org/) and "The World Bank Group" (http://sdwebx.worldbank.org/climateportal/) to determine the average annual precipitation of provincial capitals in Iran and Afghanistan for more accuracy. We also used "Climate-Data. Org." website to determine monthly average high and low temperatures for both Iran and Afghanistan. Climate-Data.org is based on two data sources: Climate-Model by Climate-Data.org: All of the climate data comes from a climate model. The model has more than 220 million data points and a resolution of 30 arc seconds. The model uses weather data from thousands of weather stations from all over the world. This weather data was collected between 1982 and 2012 . Location Data by OpenStreetMap.org: All of the location data for the cities is based on data from the OpenStreetMap project. OpenStreetMap is open data, licensed under the Open Data Commons Open Database License (ODbL). The map tiles are licensed under the Creative Commons Attribution-ShareAlike 2.0 license (CC BY-SA). The OpenStreetMap data has not been modified.

x) Climate-Data. Org. See note ix).

xi) The photograph is taken by Nakayama Mitsuteru in 2001 for Digital Silk Road Project, National Institute of Informatics, Japan. 


\section{和文要約}

本研究は、イランからアフガニスタンにかけて見られるドーム状ヴ オールト屋根伝統住居の分布特性を明らかにすることを目的として いる。イランについては高解析度の衛星写真と古い写真及び文献、ア フガニスタンについては衛星写真と現地調查の結果を分析のための 資料として用いている。

分析の結果、ドーム状ヴォールト屋根伝統住居が分布する範囲は、 イラン東部からアフガニスタン西部にかけての伝統的なペルシャ文
化圈に含まれる地域の内、年間降水量が $400 \mathrm{~mm}$ 未満の乾燥地帯である 事が明らかになった。また、その伝播の時期に関する一つの仮説とし て、アッバース朝以降、ティムール朝からサファヴィー朝にかけての 可能性があることを示した。ただしこの仮説を確かめるためには、イ ランおよびアフガニスタンにおける詳細な現地調查が必要である。

(2018 年 6 月 9 日原稿受理, 2019 年 3 月 6 日採用決定 $)$ 